\title{
The Place of Urban Cultural Heritage Festivals: The Case of London's Notting Hill Carnival
}

\author{
Ernest Taylor and Moya Kneafsey
}

\begin{abstract}
Urban cultural heritage festivals have a long tradition of contributing to the cultural and economic development of towns and cities around the world. Moreover, the increasing role of culture in city making has rendered them spaces of consumption, entertainment, pleasure, and festivity. Large European events such as London's Notting Hill Carnival, Berlin's Carnival of Cultures, and the Rotterdam Summer Carnival attract huge global audiences. Despite being mass gatherings where representations can be extreme, virtual, and somewhat fleeting, the intensity and intimacy of social interactions generated at festivals can induce a sense of belonging. Festivals are thus sites where community values, identity and cultural continuity are performed. In this sense, they are connected to cultures and to places, can help bind people to their communities, foster and reinforce group identity, and are central to the transmission of tradition. The ephemerality of festivals, as well as the inconvenience, expense, and gentrification-effects to which such large scale events can contribute, has led to questions about their ability to sustain community cohesion and socioeconomic wellbeing. Drawing on the example of London's Notting Hill Carnival, this chapter explores the extent to which urban cultural heritage festivals can be regarded as catalysts in the promotion of community cohesion. Findings from this exploratory study suggest that the event promotes a sense of belonging and cohesion in an urban space, particularly amongst younger age groups in the community, as well as festivalgoers more generally.
\end{abstract}

E. Taylor $(\bowtie) \cdot$ M. Kneafsey

Coventry University, Coventry CV1 5FB, UK

e-mail: ernesttaylor@hotmail.com; apy034@coventry.ac.uk 


\section{Introduction}

Urban cultural heritage festivals have a long tradition of contributing to the cultural and economic development of towns and cities around the world. Large European events such as London's Notting Hill Carnival, Berlin's Carnival of Cultures, and the Rotterdam Summer Carnival have gained international recognition, attracting huge global audiences, income, and reputation. Urban cultural heritage festivals have become a major influence on city making and the globalising of economies, as "spaces of consumption", entertainment, pleasure, and festivity (Eizenberg and Cohen 2014). Despite being mass gatherings where representations can be extreme, virtual, and somewhat fleeting, the intensity and intimacy of social interactions generated at events can induce a sense of belonging. Getz (2010: 2), for example, argues that festivals are spaces where "community values, ideologies, identity and continuity" are performed. Moreover, festivals are connected to cultures and to places, can help bind people to their communities, foster and reinforce group identity, and are central to the transmission of tradition (Getz 2010). However, the ephemerality of festivals, as well as the inconvenience, expense, and gentrification-effect to which such large scale events can contribute, has led to questions about their ability to sustain community cohesion and socio-economic wellbeing. Moreover, as such events grow in size and complexity, the necessary attention to crowd safety, logistics, and health can shift the feeling away from a sense of joyful 'spontaneity' towards a sense of 'serious fun,' carefully planned and controlled by festival managers, who arrange programmes for audiences, invite performers, organise security and otherwise "act as gatekeepers" (Jeong and Santos 2004: 641).

Drawing on the example of London's Notting Hill Carnival, this chapter explores the extent to which urban cultural heritage festivals can be regarded as catalysts in the promotion of community cohesion. Despite organizational, financial, and social challenges, the Notting Hill Carnival is now in its 50th year and has grown to become Europe's largest street festival, a symbol of London's cultural heritage and diversity and a major revenue earner. Findings from this exploratory study suggest that the event promotes a sense of belonging and cohesion in an urban space, particularly amongst younger age groups in the community as well as amongst the festivalgoers. This results from the carnival's origin as a communityled celebration of togetherness and its year-round contribution to community leadership and management, events, educational activities, and economic spin offs. The chapter is based primarily on a review of secondary data, supplemented with participant observation, and interviews with key individuals involved in the festival at managerial level. These were identified using purposive sampling (Bryman 2008). In addition, a limited number of participants at the festival were interviewed using opportunity sampling (Patton 2002). 


\section{Community Cohesion}

The word cohesion is often prefixed by terms such as community, social, and territorial. It refers to a sense of togetherness and connectedness between groups or individuals, usually in a defined geographical area, such as region, city or neighbourhood (Turok and Bailey 2004; Hamez 2005). The appeal of cohesion lies in its perceived capability of wholesomeness and it has been regarded as a solution to problems of increasing fragmentation, conflict, and inequality between different social and ethnic groups (Turok and Bailey 2004). Coherent policies and measures, it is argued, can build strong relationships among diverse individuals and groups, improve health and wellbeing and contribute to the cultural and socioeconomic development of specific geographical locations (Novy et al. 2012). At a European territorial level, cohesion is seen as integral to the promotion of economic, social and cultural integration (Suto et al. 2010). An estimated 346 billion Euros-35 \% of the EU budget between 2007 and 2013-was invested in cohesion initiatives such as job creation, infrastructure improvements, equal opportunities, wellbeing, and social inclusion (European Union 2013). Even though policies and measures aimed at achieving cohesion are wide-ranging and complex, at their heart, they seek to recognise and celebrate diversity and yet also create a sense of belonging to a social context, which provides meaning and identity to members.

Turok and Bailey (2004) identified five dimensions of cohesion-equality and inclusion, social connectedness, common social values, social order, and place attachment. They argue that cohesion promotes equality of status and opportunity to ensure people's circumstances do not become barriers and prevent them from realising their full potential (Turok and Bailey 2004). Inclusion encompasses social solidarity and public policies to minimise inequality of employment opportunities or access to other resources, which are critical to mitigate against social exclusion. Turok and Bailey (2004: 176) argue that inequality is a root cause of "poorer social relationships, more violence, less involvement in community life, worse health and a lower quality of life for society overall'. Social connectedness is linked to strong social relationships and networks, sense of belonging and identity, and cooperation and trust among individuals and wider society. Common social values pertain to cohesive practices, which encourage shared "moral principles" and "sets of rules and codes of behavior" (Turok and Bailey 2004: 182). Moreover, the idea of cohesion suggests social order and tolerance between groups and communities. Place attachment or territorial identity is also an important feature of cohesion in that it represents a basic human need-a sense of belonging. Turok and Bailey (2004: 176) believe experiences of place resonate with ideas of cohesion in terms of shaping people's culture and identity. 
Despite being quintessentially ephemeral, urban cultural heritage festivals present a microcosm of these varying themes of cohesion. As noted by Ferdinand and Williams (2012) festivals are intrinsic to all societies-celebrating and promoting cultural heritage and identity, regenerating communities, creating jobs and economic opportunities, and attracting audiences. Del Barrio et al. (2012): 243) point to a "festivalisation" of cities, where events generate intense spending, fashion new urban images, spark cultural creativity and social cohesion, provide new urban facilities, and generate political interest in enhancing locals' sense of belonging. Critically, Eizenberg and Cohen (2014: 54) believe festivals have positioned culture as a fundamental dimension in urban strategies. In this context, Attanasi et al. (2013: 228) argue that scores of local organisations are now becoming conscious that the "mutual valorization" of the intangible and tangible resources of a place can unlock the key dynamics of regional development. The fact that there are hundreds of thousands of urban cultural heritage festivals staged across Europe, means there is recognition of the contribution they make economically, socially, environmentally, culturally, and cohesively.

Urban cultural heritage festivals are a fusion of historical and contemporary cultural heritage, "which are brought together and displayed, as part of the process of re-interpreting cultural legacy" (Del Barrio et al. 2012: 236). Events provide a space in which people can "(re)present their past, celebrate their existence and reinterpret stories and myths about their culture" (Quan-Haase and Martin 2013: 524). An example of this is to "play mas", which is a main feature of the Notting Hill Carnival, which has its roots in African Caribbean migration to Britain after the Second World War (Ferris 2010: 520). The word 'mas' is a derivative of masquerade, which in European tradition implies wearing a facemask. However, the Caribbean genre emphasizes how the person playing mas animates the character they are portraying by drawing on their own internal cultural connectedness (Ferris 2010: 520). In this context, urban cultural heritage festivals synthesize an emotional interplay between performers, the inner self and the revelers, who line the streets.

Moreover, urban cultural heritage festivals offer people the opportunity to try new practices or give those who live locally a break from the everydayness of urban life. Events are also representative of cultural heritage, as a key strategy in urban development and are often named after the location where they are held (Eizenberg and Cohen 2014). Over a period of time, locals and the area can become intertwined with an event. As a product that is shaped, primarily, by experiences (Ferdinand and Williams 2012), festivals are characterised by festivalgoers and what they feel or believe they are connected to. Attracted by the perception, experience, attachment to place and sense of belonging generated by festivals, people may even relocate to an area in which an event is held, in some cases triggering local gentrification (Martin 2005), as is the case with the West London district of Notting Hill. However, festivals are multidimensional entities and can be billed around cultural heritage themes such as music, food, dress, sport, art, craft, drama, gender, spirituality, etc. While some urban events can be confined to parks or an area of open 
space, others occupy vast expanse of suburbs with throngs of people celebrating in the streets, dancing, eating, and drinking. In this regard, urban cultural heritage festivals can become culturally connected to the way of life, practices, and behaviors of locals.

For some revellers, urban cultural heritage festivals are a pilgrimage to where they can satisfy their desire for a congenial space to mingle carefree with a trust that belies the instantaneity of their acquaintances and the occasion. Urban cultural heritage festivals thus assume the role of a "virtual community" (Attanasi et al. 2013: 243) where festivalgoers act and behave as if they know each other, are engaged in relationships, or have shared a connection over a period of time. In highlighting the ritualistic nature of festivals, Quan-Haase and Martin (2013: 525) argue that the intrigue of events may be rooted in their role of signifying the reversal of normal power structures, a "suspension of reality and a unification of society". At some events, there is heavy use of alcohol and recreational drugs, as well as sensual dancing and general frivolity. A temporary suspension of usual behavioural inhibitions is a feature and a main attraction of many festivals (Matheson et al. 2014).

Urban cultural heritage festivals can create favourable attitudes or raise awareness about certain topics or activities (Organ et al. 2014). These can, in turn, induce behavioural change in festivalgoers depending on their level of engagement and the emotions evoked. Sampling different types of edibles at a food festival, for example, may stimulate tastes or choice for certain foodstuffs in the future. Similarly, a music festival could help foster a liking for a musical genre not previously encountered. If these tastes, choices, or encounters, experienced at festivals are triggered during routine activities away from events, they may become habitual practices. Furthermore, the consumption of festivals intertwines with emotion and hedonism, which mean the more pleasure derived from events, the more satisfied festivalgoers are and are likely to make a return visit or attend similar activities (Grappi and Montanari 2010). Correspondingly, factors at festivals that influence togetherness and unity could engender cohesion in the same way. Moreover, this is not just restricted to being physically present at events, as the prevalence of digital media has ensured that occurrences unfolding at festivals extend beyond the local. It means festivals now have wider and diverse cultural connections, influence, and participation.

\section{The Origins and Development of the Notting Hill Carnival}

I could see the streets thronged with people in brightly coloured costumes, they were dancing and following bands and they were happy. Some faces I recognized, but most were crowds, men, women, children, black, white, brown, but all laughing (Laslett 1989, cited by Blagrove 2014). 
The roots of London's Notting Hill Carnival are etched in African Caribbean culture. Britain was experiencing serious labour shortages following the Second World War and began recruiting workers from former territories such as those in the Caribbean. Faced with hardships, social exclusion, and missing 'home', the new arrivals felt the need to band together to organise their own social events and activities (Muir 2011). In this way, they could meet and interact with each other freely thus creating a home away from home and social solidarity fostering a sense of cohesion, common identity, and satisfying a sense of belonging. The urgency of meeting this need for psychological and emotional wellbeing became even more pronounced after the race riots, which erupted in Notting Hill in 1958 (Muir 2011). The following year, Claudia Jones, a Trinidadian communist, activist and publisher, who had been barred from the United States of America, organised a carnival style event in St Pancras Town Hall, London, both as a statement to the British public and a 'comfort' to the dispirited migrants (Muir 2011). The actual forerunner to today's carnival was orgainsed by Rhaune Laslett, who was born in London's East End to a Native American mother and a Russian father. In 1964, Laslett, a social worker, had a vision of people in Notting Hill coming together and celebrating in the streets. She felt that even though there were various migrants living in the congested area, there was little communication or interaction between them. Her dream of a unifying concept was realised with marchers and steel bands taking to the streets under the banner of the Notting Hill Fayre and Pageant in joyous revelry. The essence of jollification and togetherness of Laslett's event has remained an essential facet of today's carnival, which is now seen as the "largest expression of multiculturalism in the UK and has done much to bring communities together" (Greater London Authority (GLA) 2004). The event annually features an estimated 10,000 participants from Britain and other parts of the world. They take part in musical forms, costume parades, arts and crafts, provide food and drink, and stage various activities and entertainment aimed at children and adults. The Federation of European Carnival Cities (FECC), a pan-European body set up to promote and preserve carnivals, lists Notting Hill as the biggest event of its type on the continent.

The Notting Hill Carnival is rooted in ideas of identity, sense of belonging, cultural connectedness, and promoting community cohesion. The event serves as a social space and forum where intangible and tangible cultural heritage is sustained, created, shared, and enjoyed by local residents as well as visitors from Europe and other parts of the world. The carnival has become synonymous with the area of the Royal Borough of Kensington and Chelsea and is now firmly arranged in the cultural mosaic of London and Europe. It annually attracts an estimated one million people. Globally, only Brazil's Rio Carnival, in terms of urban street festivals of this type, surpasses the number of people who attend Notting Hill. Five of the eight per cent of international visitors to the carnival are from Europe (GLA 2004). The Rotterdam Caribbean Summer Carnival, which started in 1980 and Berlin Carnival of Cultures have been inspired by Notting Hill.

It is difficult to ascertain the latest economic impact of the Notting Hill Carnival, as the first and most recent study was conducted in 2002. That report, commissioned by the former London Development Agency, showed the carnival contributed in 
excess of $£ 93$ million to the city and supported the equivalent of 3000 full time jobs (GLA 2004). An estimated $£ 36$ million was spent on food, drink and other merchandise at the carnival's 250 licensed trading sites and a further $£ 9$ million on accommodation (GLA 2004). Other economic beneficiaries include music producers, clothing designers, merchandisers, and security firms. More than 90,000 foreign tourists, mainly from Europe, annually attend the event. However, the majority of visitors, who are mostly aged $16-34$, are from London and other parts of the UK. Such numbers of people offer huge scope for commercial sponsorship, celebratory art form, job creation, skills training, marketing, and merchandising (GLA 2004). With $40 \%$ of global tourism revenues emanating from intangible and tangible forms of cultural assets (United Nations 2012), Notting Hill Carnival has the potential to tap into the lucrative cultural tourism market across Europe and further afield. Furthermore, iconic London with its distinctive characteristics, lifestyles, heritage, cultural activities, and landscape, adds to the inherent appeal of the carnival.

\section{Promoting Community Cohesion}

The Notting Hill Carnival began with the objective of building and creating community cohesion. Historically, the event has been a catalyst for mobilisation against racism, poor housing conditions, extortionate rent, and overcrowding, experienced by local working class people in the Notting Hill area. It gives voice to minorities and the marginalised: "Carnival allows people to dramatise their grievances against the authorities on the street, when parliament or other spaces of influences are closed off to them" (Dabydeen 2010). As Tompsett (2005: 46) argues, "claiming public space, is at the heart of Notting Hill Carnival. In this sense, the road is seen as a commemorative space with possession of the street etched in the memory and the psyche, the right of free people to occupy the public thoroughfare." Moreover, "it connects past to present" (Tompsett 2005: 46).

The contemporary vision of the Carnival, which is now run by the London Notting Hill Carnival Trust is to "foster the creative development and enhancement of diverse artistic excellence, thus transforming perceptions of London Notting Hill carnival culture locally, nationally and internationally" (Notting Hill Carnival 2015). Its mission is to use carnival arts collaboratively and artistically as a catalyst to facilitate "artistic excellence, education, engagement, empowerment, entertainment, integration, transformation of perceptions, inspiration" (Notting Hill Carnival 2015). From these statements, it can be seen that the carnival fosters a dynamic sense of cultural identity which is clearly oriented towards the perceptions of audiences and participants within the local community and beyond. Claire Holder, former chief executive of the Notting Hill Carnival Trust, who now runs the Notting Hill Carnival Roadshow, a carnival entertainment touring company, and believes events like Notting Hill Carnival are ideally placed to achieve community cohesion, because of the "pressures and diversity" of the urban contexts in which they are situated (Holder 2014). Notting Hill is rooted in the history of the African 
Caribbean experience in Britain, explains Holder. Many of today's carnival participants are descendants of those, who were invited to the UK to help rebuild the 'Mother Country' after the Second World War. Some of the first arrivals had settled in the overcrowded tenements of the North Kensington district alongside the working class British, Irish, Jews, Greeks and Spaniards. Here they faced exploitation by slum landlords and racial tension spurred on by the likes of fascist Oswald Mosley. Hostilities culminated in the 1958 Notting Hill Race Riots and the murder of Antiguan carpenter, Kelso Cochrane, by racists, the following year. Activists saw the carnival as a way of bridging cultural gaps, uniting the community and easing racial tensions. Emerging from this contested backdrop, Notting Hill Carnival has come to be acknowledged as a "joyous beacon of hope and unity" (Ferris 2010: 522).

The Notting Hill Carnival resonates with sense of belonging and togetherness and has been instrumental in laying a cultural heritage foundation for people of African Caribbean origin and their descendants in Britain today. For many, the event holds special significance as a "liberated territory" where virulent racism has been resisted (Ferris 2010: 521). Over 2-days in August every year, this corner of West London becomes an embodied zone where solidarity is openly embraced. This is particularly surprising amid ethnic tensions, rising hate politics and increased migration across Europe. It means the event has transcended its local social and political boundaries making a broader contribution to community cohesion. As Holder (2014) explains:

These festivals are not organised by government and are community-led and community driven. They only happen whenever there is a collective community will and therefore, as they evolve in their urban contexts they fulfil that role of community and territorial cohesion.

The idea of collectivity, espoused here, illustrates the fact that the Notting Hill Carnival is about group action, individuals working together, relationships and cooperation. It is these practices that underpin the foundation for togetherness and solidarity of people cohering in a "collective community will", an interrelated effort (Holder 2014). Portraying such events as "community-led" and "communitydriven" shows that the notion of cohesion is more than people coming together or merely a social inclusion function (Holder 2014). It is also about empowering people to make choices and having the "will" (Holder 2014) to create the type of environment in which they feel they belong and want to be a part of, irrespective of their circumstances. Holder's (2014) "collective community" is also a counter to the "increasing individualism", which has led to unease about social disintegration, conflict and crime, lack of respect for civic institutions, systematic marginalisation of certain social groups and their geographical concentration in poor areas (Turok and Bailey 2004: 144). In this sense, Holder's notion of community and territorial cohesion encompasses economic, social and environmental concerns; disparities and accessibility to services and opportunities, at both national and local levels, contemporaneously and in the future (Hamez 2005). Urban cultural heritage 
festivals are, therefore, not just one-dimensional entities, but multifaceted events incorporating spatial, sustainability, and temporal attributes of cohesion.

Whilst acknowledging Notting Hill Carnival's important economic and political role, Holder stresses that it is important for the event make a positive contribution to wider society: "If it does not do this, then it is just entertainment. Festivals such as Notting Hill far transcend that entertainment value and are important vehicles for self-actualisation" (Holder 2014). A sense of belonging is thus bound up with notions of cohesion, as it provides a rationale for a meaningful existence, of being part of or identifying with something and serving a purpose, both to one's in-group and society, more broadly.

In the foreword of his Strategic Review of the Notting Hill Carnival, Ken Livingstone, the former Mayor of London, argues that the event has "succeeded in promoting a fusion of cultures, people and customs" (GLA 2004: 6). This observation was borne out on the Sunday of Notting Hill Carnival 2014 when black carnival goers were visibly in the minority. Even though the event has had a history of predominantly attracting people of African Caribbean origin, this is no longer, strictly, the case. The diversity of people now attending Notting Hill Carnival is certainly reflective of Livingstone's fusion of cultures, people and customs. The vividness of intercultural interactions, different foods, musical genres, entertainment, dress, costumes, parades, languages, rituals, behaviours, and displays all occurring in the name of the carnival, produces strong images of unity. Citing Allport's (1954) contact theory, Lee et al. (2011) argue that positive, personal, and cooperative contact between different groups can reduce or eliminate prejudices. In this regard, events such as cultural heritage festivals, not only help minority groups maintain their own culture of origin, but also augment connections with the dominant population and other groups thus breaking down biases (Lee et al. 2011). This suggests that the Notting Hill Carnival provides a space where linkages extend beyond their bounds appealing to a diverse audience. Lee et al. (2011) argue cultural heritage festivals are an effective resource for promoting social harmony and integration. According to Holder (2014),

The Notting Hill Carnival was incepted with the idea of bringing the 'black' community together. It was about racial integration. Remember the black community at the time had come from many different Caribbean islands and were not mixing. In time, this togetherness, the entertainment value and ethos of a celebration of freedom, appealed to others who subscribe to that spirit.

Even though Notting Hill Carnival is rooted in African Caribbean culture, it is something that "we want everyone to be a part of and enjoy", explains (Benn 2014), a trustee of Notting Hill Carnival Enterprise Trust. Providing the opportunity for people to experience other cultures, argues Benn, helps them appreciate their own, breaks isolation and broadens their worldview of what the world is all about; "The idea of the world as a melting pot of cultures all coming together is encapsulated in the Notting Hill Carnival" (Benn 2014). The idea of togetherness that Benn rationalises is bound up with notions of identity, in relation to what the event 
represents and cultural connectedness, in terms of the cultural heritage that is realised at the carnival. The event thus provides an embodied space where the journey from the past coalesces with the present materialising in a connected whole.

For Benn, the Notting Hill Carnival is a medium that amplifies awareness of African Caribbean cultural heritage across Europe and beyond. The event, which he describes as "inclusive and cohesive", is something he wants everyone to be a part of and to share with each other. While this objective corresponds with a sense of belonging, it also coincides with the carnival's perceived broader societal endowment. As the largest cultural event in London, Benn says Notting Hill Carnival has become synonymous with the UK's capital and is representative of the diversity that exists there. This suggests that the attachment to place inherent in the carnival embodies London as a whole and is not just about the Notting Hill enclave. This broader representation is part of the "festivalisation" of cities (Del Barrio et al. 2012: 243) with events becoming pluralised in terms of their economic, environmental, cultural, political, and social impacts on urban landscapes. Such is their influence that even though a sense of belonging is an important benefit of urban cultural heritage festivals, it is only one facet in a complex whole.

For some carnival performers or 'masqueraders' and costume designers, the Notting Hill Carnival is a perennial activity. Preparations usually start the day after the carnival ends with the selection of themes and costume designs for the forthcoming year. Most masqueraders are members of bands, each of which can number up to 500 or more people. More than 50 bands participated in Notting Hill Carnival 2014. The bands are diverse in terms of members, age, sex, race, code of conduct, etc. Costumes are categorised as background, frontline, individual, and king or queen designs. In bands such as London's United Colours of Mas (UCOM), costumes are priced in the region of $£ 200-400$ (background), $£ 400-500$ (frontline) and from $£ 600$ for an individual design. Throughout the year, bands hold regular carnival themed events for members and other activities such as trips or competition at other festivals around the world. The way bands operate means they are a key feature of the actual carnival event, source of participants, cohesiveness, and sustainability.

Jenny ${ }^{1}$ is a member of UCOM and masqueraded in an individual costume at Notting Hill Carnival 2014. Now aged 30, she has been attending carnivals from as far back as she can recall. For her, being a member of a carnival costume band and actually taking part in the event itself, adds not only to cohesiveness, but also to her emotional and psychological wellbeing. She argues that playing mas in a scantily clad costume in front of thousands of people has helped to improve her self-esteem and confidence. Carnival has also led to a greater appreciation of her cultural heritage and other people's way of life. Jenny believes these considerations are key to the sustainability of carnival and in educating people about aspects of the cultural heritage that underpins events such as Notting Hill. She contends that attending the Trinidad and Tobago Carnival and taking part in the Berlin Carnival

\footnotetext{
${ }^{1}$ Not her real name.
} 
of Cultures has enlightened her about different cultures other than her own. Such is the increasing diversity of cultural heritage festivals; Jenny believes events like Notting Hill are assuming a fluid identity where cultural heritage, community and territorial representations have become blurred.

Berlin's carnival is called Carnival of Cultures and that is very interesting, because you go there as a Caribbean band and you are one band out of 50 different cultures. You've got skateboarders, you've got people from China, you've got people from Japan, you've got Jamaican people, you've got people wearing 1920s flapper girls, so depending on eras, cultures, styles; anything you want. You can have a float and that is represented and I think that's probably where Notting Hill is going. It is not gonna be typically a Caribbean carnival. It's gonna be more of a cultural, any culture represent-bring good vibes, bring good spirit; showcase who you are, what you are about: have a good time (Jenny 2014).

The fluidity of carnival, highlighted by Jenny, is supported by bands such as Holder's Notting Hill Carnival Roadshow, a commercial spin-off, which, like UCOM, operates throughout the year, as an entertainment touring company. The roadshow runs costume workshops, seminars, steel band hire, carnival catering, schools workshops, carnival design, and carnival management services. The company also participates in various festivals such as the Seychelles Carnival and the Abuja Carnival in Nigeria. As a by-product of Notting Hill Carnival, the continuous activities of such bands, is a major contribution to the sustainability and promotion of the London event. Holder argues that such attributes not only apply to sustainability, but also to cohesion. Preparations and activities associated with Notting Hill, she contends, means participants are building the cohesion and social capital in their own communities before they attend events.

The biggest input that the carnival body make to that cohesion is to foster that sense of togetherness by bringing the disciplines and community together at least three to four times a year in joy, harmony and working towards the same goal of development of the carnival (Holder 2014).

These observations indicate different ways in which the cohesiveness generated by urban cultural heritage festivals is maintained beyond the moment of the event. The open-ended and multidimensional nature of festivals also gives rise to transnational networks or pluralised cultural heritage forms where various traditions are merged under a single banner, none preeminent among the others. It means festivals, though situated in terms of place identity, are neutral independent zones of "joy" where happiness among different people is the prevailing theme (Jaeger and Mykletun 2013: 224). This embodied space, where notions of belonging and togetherness are transformed, contested and communicated, may have as much to do with the sustainability of urban cultural heritage festivals, as any other factor.

Another impact of Notting Hill is its social enterprise contribution. One of the reasons the carnival has enduring impact within the local community is because it generates jobs and activity all year round. This is typified by Mahogany, a limited company run as a not-for-profit social enterprise and receiving funding from the Arts Council of England and Wales. The company first appeared as a costume band 
at Notting Hill Carnival in 1989 and contributes to the business of carnival and preserving its cultural heritage by making costumes all year round for various events across the world. A main focus of the project is helping underprivileged young people develop their skills and build greater confidence through the art of carnival.

\section{$5 \quad$ Challenges to Community Cohesion}

One of the major concerns of participants in this study is the indication that the Notting Hill Carnival has become a victim of its own success. The district in which it is held is a high-density residential area and has to accommodate more than one million people, some stimulated through alcohol or other substances, causes problems in relation to anti-social behaviour, public convenience, overcrowding, litter, etc. The area has also been subjected to increased gentrification. In the mid-nineteenth century, the outer London district became home to the capital's wealthier inhabitants fleeing the inner city only to become a dilapidated enclave in the 1950s housing migrants and those experiencing extreme poverty (Martin 2005). The area, which was seen as an area of deprivation and racial tension, has today gained the reputation as one of London's most fashionable suburbs with homes belonging to the capital's high-flying business people, celebrities and politicians including the Conservative Prime Minister David Cameron and Chancellor of the Exchequer George Osborne. A popular film, which bears the name of the district, has garnished the area's international appeal. Such has been the metamorphosis of Notting Hill that there are fears the area may not only lose its carnival, but also its identity.

Remybyn, ${ }^{2}$ who is in her 40s, has lived in Notting Hill and other parts of North Kensington all her life. She runs a stall outside her home selling barbecued gourmet burgers. She confessed that the venture was not purely for financial gain, but a way of being involved in carnival and providing a local meeting point for fellow residents, some of whom had contributed to the enterprise by giving her disposable tableware products, extending storage space to her, and generally lending a helping hand where needed. Remybyn insists the area is a nice place to live.

You could leave your house in the morning and say you are going to the shops and not come back for two or three hours or even longer on a sunny day. You might bump into people and you stop and chat or you might know a stallholder or people you see everyday; you might not even know their names, but you stop and talk or they talk to you. It is lovely, a really lovely area to live in particularly in the summer when it is warm, you will find everyone out in the streets either sitting on their doorsteps having a cup of tea or drinking or just milling around the market—it is just a nice place to be, a safe place to be (Remybyn 2014).

\footnotetext{
${ }^{2}$ Not her real name.
} 
Even though Remybyn insists that the community spirit in the area exists all the time, she argues that things are changing. The popular Portobello Road Market, which she contends, is the hub of the community, like other small businesses in the area, is facing competition from the high street chains springing up in the district:

One of the charms of the area, until recently, is we have managed to resist a lot of high street chains in Portobello Road. We are made up of a lot of independent shops that are run by local people. We have market traders whose family have been there for 100 years, but now also own multi million pound houses, because their family bought them back in the fifties or sixties and those properties are now worth a fortune, and yet the family still trade on the markets. It is such a diverse community. When I first came to the area, I could not get a cab to drop me to certain parts of the area, All Saints Road, for instance, been one of them. When I lived there, for a brief period, with a friend, it was known as the 'frontline' and the cab driver would drop me two or three streets away and say, 'Am not going there luv' and leave me with a carry cot and a young baby, but now you could go down there and find Prince Harry parked in the Rum Kitchen and it is quite a well to do road - there has been a lot of change (Remybyn 2014).

Not all the recent changes in Notting Hill can be pinned on the carnival; Remybyn argues that the locating of several high street chains in the area has meant increasing commercialisation, which could lead to a loss of "community feel". She also revealed that recent newcomers to area "hate the carnival" and this has added fuel to the speculation that the authorities want to move the carnival to Hyde Park. Losing the event and the on-going gentrification would suggest a complete alteration of the social dynamics of Notting Hill. In his study in issues related to neighbourhood change, place and identity in Notting Hill, Martin (2005) noted that working class people were more concerned about localised issues such as crime, drugs, overcrowding, local authority neglect, new migrants, and gentrification than emotional attachment to place. His middle class respondents, perhaps fixated by aesthetic appeal, appeared more concerned with the loss of traditional landscapes (Martin 2005). While such findings contradict claims (Ferris 2010; Waitt 2008) that newcomers-deemed to be prosperous homeowners-are opposed to urban cultural heritage festivals such as the Notting Hill Carnival, they also reveal the contestation surrounding such events. It is clear that the increasing numbers of such festivals being staged is a testament to their inherency to all societies in terms of celebrating and promoting cultural heritage and identity, regenerating communities, creating jobs and economic opportunities and attracting distinctive audiences. However, due to their heterogeneity in terms of cultural, social, economic, and environmental contribution, urban cultural heritage festivals reside in an embodied space in which notions of belonging and cohesion are transformed, contested, and communicated.

\section{Conclusion}

The findings of this study suggest the increase in urban cultural heritage festivals can be linked to an appreciation of activities promoting greater diversity and a sense of belonging and cohesion in urban spaces. The study suggests that urban cultural 
heritage festivals such as London's Notting Hill Carnival can be effective tools in building strong, coherent and balanced social relationships among diverse populations. Formed to counter tension and unease, the event has been instrumental in laying a cultural heritage foundation for people of African Caribbean origin and their descendants in Britain today. Moreover, the organisers' mantra of inclusivity and cohesiveness has engendered the carnival to the wider community in terms of participation and attendance. Findings suggest urban cultural heritage festivals such as Notting Hill Carnival thus provide an embodied space in which ideas of belonging and community and territorial cohesion are transformed, contested and communicated. This indicates that participants are attracted to the event because they can identify with its rationale in terms of their co-existence with their in-group and society more broadly.

The findings further indicate that urban cultural heritage festivals such as Notting Hill are multifaceted activities providing economic benefits, social empowerment and sustaining cultural heritage. However, the study was limited in that the broader economic benefits of the Notting Hill Carnival were not fully explored and neither were the effects of notions such as place attachment and gentrification on the hosting of such events. There is a need for more in-depth and substantial research to examine critical questions about how different sub-groups within local communities interact with large-scale cultural events, especially as large urban populations tend to have a mix of long-established residents alongside many new arrivals and transient groups. There are also further questions about how festivals are organized, how decisions are taken and how diverse groups (according to age, gender and ethnicity, for instance) can be involved. Future research could examine these areas and also investigate the cohesiveness of urban cultural heritage festivals in districts that are not as diverse as Notting Hill to gain a more holistic picture of their influence on community and territorial cohesion.

Open Access This chapter is distributed under the terms of the Creative Commons AttributionNoncommercial 2.5 License (http://creativecommons.org/licenses/by-nc/2.5/) which permits any noncommercial use, distribution, and reproduction in any medium, provided the original author(s) and source are credited.

The images or other third party material in this chapter are included in the work's Creative Commons license, unless indicated otherwise in the credit line; if such material is not included in the work's Creative Commons license and the respective action is not permitted by statutory regulation, users will need to obtain permission from the license holder to duplicate, adapt or reproduce the material.

\section{References}

Attanasi, G., Casoria, F., Centorrino, S., \& Urso, G. (2013). Cultural investment, local development and instantaneous social capital: A case study of a gathering festival in the South of Italy. Socio-economics, 47, 228-247.

Benn, L. (2014). Director of London Notting Hill Carnival Limited. 
Bryman, A. (2008). Social Research Methods (3rd ed.). Oxford: Oxford University Press.

Dabydeen, D. (2010). Notting Hill Carnival. Coventry: Knowledge Centre, University of Warwick.

Del Barrio, M. J., Devesa, M., \& Herrero, L. C. (2012). Evaluating intangible cultural heritage: The case of cultural festivals. City, Culture and Society, 3, 235-244.

Eizenberg, E., \& Cohen, N. (2014). Reconstructing urban image through cultural flagship events: The case of Bat-Yam. Cities, 42, 54-62.

Union, E. (2013). EU cohesion policy contributing to employment and growth in Europe'. Social Affairs \& Inclusion: Directorates-General for Regional \& Urban Policy and Employment.

Ferdinand, N., \& Williams, N. L. (2012). International festivals as experience production systems. Tourism Management, 34, 202-210.

Ferris, L. (2010) Incremental art: negotiating the route of London's Notting Hill Carnival. Social Identities, 16 (4), 519-536

Getz, D. (2010). The nature and scope of festival studies. International Journal of Event Management Research, 5(1), 1-47.

Grappi, S., \& Montanari, F. (2010). The role of social identification and hedonism in affecting tourist re-patronizing behaviours: The case of an Italian festival. Tourism Management, 32, $1128-1140$.

Authority, G. L. (2004). Notting Hill Carnival: A strategic review. London: Greater London Authority.

Hamez, G. (2005). Territorial cohesion: How to operationalize and measure the concept? Planning Theory and Practice, 6(3), 400-402.

Holder, C. (2014). Former Chief Executive of the Notting Hill Carnival Trust.

Jaeger, K., \& Mykletun, R. (2013). Festivals, identities, and belonging. Event Management, 17, 213-226.

Jeong, S., \& Santos, C. A. (2004). Cultural politics and contested place identity. Annals of Tourism Research, 31(3), 640-656.

Laslett, R. cited by Blagrove Jr, I. (2014, August 7) 'Notting Hill Carnival-The untold story'. London Evening Standard.

Lee, I., Arcodia, C., \& Lee, T. J. (2011). Benefits of visiting a multicultural festival: The case of South Korea. Tourism Management, 33, 334-340.

Martin, G. P. (2005). Narratives great and small: neighbourhood change, place and identity in Notting Hill. International Journal of Urban and Regional Research, 29(1), 67-88.

Matheson, C. M., Russell Rimmer, R., \& Tinsley, R. (2014). Spiritual attitudes and visitor motivations at the Beltane Fire Festival, Edinburgh. Tourism Management, 44, 16-33.

Muir, H. (2011, August 25). The importance of the Notting Hill carnival'. The Guardian.

Novy, A., Swiatek, D. C., \& Moulaert, F. (2012). Social cohesion: A conceptual and political elucidation. Urban Studies, 49(9), 1873-1889.

Organ, K., Koenig-Lewis, N., Palmer, A., \& Probert, J. (2014). Festivals as agents for behaviour change: A study of food festival engagement and subsequent food choices. Tourism Management, 48, 84-99.

Patton, M. Q. (2002). Qualitative Research and Evaluation Methods. London: Sage.

Quan-Haase, A., \& Martin, K. (2013). Digital curation and the networked audience of urban events: Expanding La Fiesta de Santo Toma's from the physical to the virtual environment. International Communication Gazette, 75(5-6), 521-537.

Suto, A., Salamin, G., \& Szabo, P. (2010). Issues of territoriality and territorial cohesion in the revision of the TSP and the territorial agenda-A sort of connection between geography and regional. Forum Geografic, 9, 145-154.

Tompsett, A. R. (2005). 'London is the place for me': Performance and identity in the Notting Hill Carnival. Theatre History Studies, 25, 43-60.

Turok, I., \& Bailey, N. (2004). Twin track cities? Competitiveness and cohesion in Glasgow and Edinburgh. Progress in Planning, 62, 135-204. 
Nations, U. (2012). UN System Task Team on the Post-2015 UN Development Agenda-Culture: a driver and an enabler of sustainable development. New York: Author.

Waitt, G. (2008). Urban festivals: Geographies of hype, helplessness and hope. Geography Compass, 2, 513-537.

www.thelondonnottinghillcarnival.com. Retrieved November 26, 2015. 